\title{
PEMAHAMAN PENGASUH PONDOK PESANTREN TERHADAP HADITS-HADITS MISOGINIS (Studi Kasus di Pondok Pesantren di Kabupaten Ponorogo)
}

\author{
A.Muchaddam Fahham \\ Dosen Jurusan Ushuludin STAIN Ponorogo
}

\begin{abstract}
Abstrak
Gender bias in interpreting normative texts (Qur'an and Hadits) is one of significant factors to create gender inequality. The texts are interpreted by religious elites and the interpretation of the texts is accepted by society as an absolute truth which cannot be changed. This paper explores religious elite's (Ulama) interpretation on Misogyny hadith in Ponorogo of which Heads of two pesantren (kyais) were interviewed their interpretation on the hadith. The data gathered were analyzed and were descriptively presented. The result shows that the Heads (kyais) from that Islamic boardinghouse ignored the methodology of interpretation particularly on the aspect of historical critics of the the chain of transmission (sanad) and the content (matn)of hadith. The heads of the two pesantren do not have special approaches in understanding hadith. Then, their understanding of the hadith may be discriminative toward women or vice versa.
\end{abstract}

\section{A. Pendahuluan}

Hingga saat ini pandangan masyarakat terhadap perempuan masih saja buruk, perempuan cenderung dipandang sebagai manusia kelas dua yang tidak layak memimpin dan menduduki posisi-posisi kunci di berbagai ruang publik, perempuan masih cenderung ditempatkan pada posisi-posisi domestik, seperti merawat rumah tangga mengasuh anak dan memasak di dapur. Relasi laki-laki dan perempuan dalam ranah keluargapun diskriminatif, laki-laki adalah pemimpin dan penaggungjawab rumah tangga, sementara perempuan meskipun memiliki kemampuan intelektual selalu berposisi sebagai "abdi" suami yang harus taat, sekalipun suami berlaku tidak adil terhadapnya.

Tak bisa dipungkiri pada tataran empirik banyak perempuan yang berkiprah di ruang publik, tapi "upaya diam-diam" untuk memarginalkan perempuan dari ruang tersebut tetap hidup. Indikatornya jelas, perjuangan kesetaraan perempuan yang 
diperjuangkan oleh aktifis gender ${ }^{1}$ sampai kini masih marak, bahkan merambah ke isu-isu yang lebih strategis seperti pengarusutamaan gender, penghapusan kekerasan dalam rumah tangga, dan penghapusan perdagangan perempuan, dan anak.

Pertanyaan yang urgen untuk diajukan mengapa ketidakadilan gender masih tetap hidup di tengah-tengah masyarakat, padahal upaya untuk membangun kesadaran gender di kalangan laki-laki dan perempuan tak henti-hentinya dilakukan?

Jawaban atas pertanyaan itu tentu saja beragam. Ada yang menyatakan bahwa masyarakat belum sepenuhnya memahami hak-hak perempuan, pemahaman bahwa perempuan bukan manusia kelas dua yang mesti dihormati sebagaimana layaknya memperlakukan kaum laki-laki belum melekat dalam kesadaran masyarakat. ${ }^{2}$ Jawaban lain menyatakan bahwa perjuangan aktifis gender yang memperjuangkan hak-hak perempuan dan kesetaraan perempuan dalam berbagai segi kehidupan belum mendapatkan respon yang positif dari masyarakat. Respon tersebut cenderung resisten terhadap gerakan-gerakan pemberdayaan perempuan. Resistensi itu terutama berakar dari anggapan bahwa isu kesetaraan gender berasal dari Barat yang tidak patut dipedomani. Konsep tentang perempuan yang diperjuangkan oleh aktifis gender kontradiktif dengan nilai-nilai agama yang menjadi anutan masyarakat. Agama telah mengatur relasi perempuan sedemikian rupa sehingga tidak lagi perlu ada konsep atau nilai-nilai dari luar yang mengatur konsep relasi laki-laki dan perempuan.

Pertanyaan terhadap resistensi itu kemudian adalah apakah ajaran agama (baca: Islam) menempatkan posisi perempuan setara dengan posisi laki-laki, sehingga

\footnotetext{
${ }^{1}$ Kata gender berasal dari bahasa Inggris, gender. John M. Echol dan Hasan Shadily dalam Kamus Inggris-Indonesia terbitan Gramedia mengartikan kata ini dengan "jenis kelamin" tentu saja arti demikian kurang tepat sebab kata gender disamakan artinya dengan kata sex. Dengan mengutip Women's Studies Enciclopedia, Nasaruddin Umar mengartikan kata gender sebagai sebuah konsep kultural yang berupaya membuat perbedaan dalam hal peran, perilaku, mentalitas, dan karakteristik emosional antara laki-laki dan perempuan yang berkembang dalam masyarakat. Lihat Nasaruddin Umar, Argumen Kesetaraan gender dalam al-Qur'an (Jakarta: Paramadina, 1999), 33-34. Karena itu gender bukan bersifat kodrati sebagaimana sex (jenis kelamin) ia lebih pada perbedaan prilaku antara laki-laki dan perempuan yang dikontruksi oleh proses sosial budaya masyarakat yang panjang. Lihat Mansour Faqih, Analisis Gender dan Transformasi Sosial (Yogyakarta: Pustaka Pelajar, 2003), 8.

${ }^{2}$ Masyarakat tampak masih mengaggap perbedaan peran antara perempuan dan laki-laki merupakan sesuatu yang bersifat kodrati yang harus diterima dan tidak bisa dipertukarkan, padahal sejatinya tidaklah demikian. Konsep perbedaan peran yang social constructed sejatinya bisa dirubah. Tapi membangun kesadaran bahwa gender bukan merupakan sesuatu yang kodrati bukanlah sesutu yang mudah, sebab kesadaran itu telah mengendap dalam alam kesadaran mereka.
} 
perempuan dalam konsep Islam bisa saja berperan baik dalam konteks publik maupun privat? Jika jawaban atas pertanyaan itu afirmatif, tentunya tidak perlu muncul penolakan atas perjuangan aktifis gender yang secara gigih hendak menempatkan posisi perempuan setara dengan laki-laki. Tapi kenyataannya resistensi itu tetap saja muncul.

Jawaban atas resistensi itu barangkali mesti merujuk pada sumber ajaran Islam yang dasariah. Jika diperhatikan ayat-ayat al-Qur'an yang berbicara seputar perempuan ditemukan satu konsep yang menyatakan bahwa laki-laki itu lebih utama daripada perempuan (al-Rijal qawwamuna ala al-Nisa '), ${ }^{3}$ tapi disisi lain ada juga ayat yang menyatakan bahwa perempuan dan laki-laki itu dicipta dari satu nafas yang sama (min nafsin wahidah). ${ }^{4}$ Dari dua ayat tadi, dapat dipahami bahwa satu sisi ajaran Islam menempatkan perempuan sebagai makhluk yang harus ada dalam kendali lakilaki, tapi disisi lain, perempuan dan laki-laki dicipta dari nafas yang sama, itu artinya dalam konteks ajaran Islam tidak perlu ada diskriminasi relasi antara laki-laki dan perempuan, sebab ia dicipta dari nafas yang sama. Kemudian kenapa muncul diskriminasi relasi dan peran antara perempuan dan laki-laki. Apakah mungkin pemahaman atas ayat-ayat itu yang perlu ditinjau ulang. Di Indonesia, telah banyak studi yang dilakukan untuk keperluan itu, sebut misalnya adalah Argumen Kesetaraan gender dalam al-Qur'an, karya Nasaruddin Umar dan Tafsir Kebencian: Studi Bias gender dalam Tafsir al-Qur'an karya Zaitunah Subhan ${ }^{5}$. Secara umum hasil studi ini menunjukkan bahwa pemahaman terhadap ayat-ayat al-Qur'an yang berbicara seputar perempuan perlu dikaji ulang agar didapatkan pemahaman yang adil dan tidak diskriminatif terhadap perempuan.

Selain al-Qur'an sumber ajaran Islam yang kedua adalah hadis. Jika sumber ajaran ini diperhatikan maka ditemukan ada beberapa hadis yang isinya memposisikan perempuan tidak setara dengan laki-laki. Misalnya ada hadis yang menyatakan bahwa tidak beruntung suatu kaum jika urusan-urusan mereka

\footnotetext{
${ }^{3}$ Q.S. Al-Nisa:34.

${ }^{4}$ Q.S. al-Nisa':1.

${ }^{5}$ Zaitunah Subhan, Tafsir Kebencian: Studi Bias Gender dalam Tafsir al-Qur'an (Yogyakarta: LKiS, 1993).
} 
diserahkan kepada perempuan. ${ }^{6}$ Di sisi lain, ada juga hadis yang menyatakan bahwa jika seorang perempuan menolak ajakan hubungan biologis suaminya, maka malaikat akan melaknat perempuan tersebut. ${ }^{7}$

Hadis-hadis yang isinya tampak mendiskreditkan perempuan disebut oleh Fatima Mernissi sebagai hadis-hadis misoginis, yakni hadis-hadis yang membenci perempuan. ${ }^{8}$ Pertanyaannya kemudian adalah apakah dengan demikian dapat dikatakan bahwa Islam memang mengajarkan kebencian kepada perempuan? Kesimpulan demikian tentu saja tergesa-gesa, sebab kesimpulan itu tidak bisa ditarik hanya berdasarkan bunyi lahir matn hadis. Yang adil barangkali adalah mencoba melakukan pemahaman secara proporsional terhadap hadis-hadis yang disebut misoginis itu. ${ }^{9}$

Dalam tradisi Islam, pemahaman teks-teks keagamaan biasanya dilakukan oleh mereka yang memiliki otoritas keagamaan seperti ulama. Karena memiliki otoritas keagamaan, pemahaman mereka kemudian dinilai sebagai pemahaman yang memang sudah semestinya dan harus diterima sebagai pemahaman yang benar.

Di Indonesia, khususnya di kalangan pesantren, salah satu figure ulama yang biasanya melakukan tafsir atau pemahaman terhadap konsep ajaran Islam yang

\footnotetext{
${ }^{6}$ Al-Bukhari, Shahih Bukhari, (Beirut: Dar al-Fikr, t.t.), IV: 228.

${ }^{7}$ Ibid., Kitab Nikah, No. 4795.

${ }^{8}$ Lihat Fatima Mernissi, Wanita di dalam Islam, (Bandung: Pustaka, 1991), 62-104.

${ }^{9}$ Mehamami hadits perlu perangkat metodologis. Karena itu, secara metodologis setidaknya ada dua hal yang harus dilakukan sebelum memahami hadist. Pertama, melakukan kritik historis, yaitu mempertanyakan apakah hadist yang akan dipahami itu memiliki kualitas yang shahih, sehingga hadist tersebut absah dijadikan dasar sandaran sebuah perbuatan. Dalam kritik historis itu yang dilakukan adalah meneliti sanad atau rangkaian nama-nama periwayat yang mewartakan matn hadits. Yang dipertanyakan terhadap para periwayat itu adalah apakah para periwayat itu adil, tsiqah, dan dhabith. Kemudian jika telah terbukti adil, tsiqah, dan dhabith, apakah periwayatan yang terjadi bersambung (ittishal al-sanad) atau justru terputus. Selanjutnya apakah para periwayat itu terhindar dari cacat dan syadz. Tidak berhenti sampai di situ, jika sanad hadist telah terbukti valid, perlu kemudian dipertanyakan apakah matn (redaksi) hadist yang diwartakan itu juga valid. Dalam kontek ini yang perlu dilakukan adalah melakukan perbandingan antar matn, mengingat matn hadist yang semakna tidaklah tunggal. Disini akan ditemukan apakah matn hadist itu mengandung ziyadah, idraj dan lain sebagainya. Kajian lebih lanjut tentang persoalan kritik historis terhadap hadist bisa lihat pada M. Syuhudi Ismail, Metodologi Penelitian Hadis Nabi (Jakarta: Bulan Bintang, 1992). Setelah melakukan kritik historis langkah selanjutnya yang perlu dilakukan adalah memilih pendekan untuk memahami hadist. Untuk keperluan ini bisa dilihat kajian Nizar Ali, Memahami Hadist: Metode dan Pendekatan (Yogyakarta: CeSad YPI al-Rahmah, 2001). Musa Hadi Ham, Konsep Evolusi Sunnah (Semarang: Aneka Ilmu, 2002). A. Muchaddam Fahham, Hermeneutika Hadist (Ponorogo: STAINPO Press, 2004).
} 
tersebar dalam al-Qur'an dan hadis adalah kyai. Posisi kyai sangat strategis untuk menyebarkan paham keagamaan termasuk melakukan pemahaman terhadap hadishadis Nabi yang kemudian ia sebarkan kepada para santri atau masyarakat sekitar melalui pengajaran dan pengajian.

Berdasarkan posisi kyai ${ }^{10}$ yang demikian menarik kemudian untuk diketahui bagaimana kyai (dalam penelitian ini adalah pengasuh pesantren) memahami hadishadis misogini, apakah pemahaman mereka cenderung diskriminatif terhadap perempuan? Inilah masalah utama yang hendak dibahas dalam tulisan ini. Karena itu tujuan utama tulisan ini adalah hendak mengetahui pemahaman pengasuh pesantren terhadap hadis-hadis misoginis. Di samping untuk mengetahui apakah pemahaman mereka terhadap hadis cenderung diskriminatif terhadap perempuan.

Sepanjang pembacaan peneliti terhadap hasil-hasil penelitian tentang hadishadis misogini dan pemahaman terhadapnya, ada satu penelitian yang mencoba untuk meneliti pemahaman kyai terhadap hadis-hadis misogini, ${ }^{11}$ akan tetapi penelitian itu memfokuskan penelitiannya pada pemahaman kyai dan implikasi pemahaman tersebut terhadap masyarakat. Sementara penelitian yang sedang peneliti lakukan berbeda dengan penelitian tersebut. Penelitian yang akan dilakukan ini mencoba mendeskripsikan pemahaman pengasuh pesantren terhadap hadis-hadis misogini dengan melihat apakah pemahamannya cenderung tekstual dan mendiskreditkan lakilaki atau cenderung kontekstual dan menghormati harkat perempuan.

\section{B. Metode Penelitian}

Data utama yang diperlukan dalam penelitian ini adalah data tentang pemahaman pengasuh pesantren terhadap hadis-hadis misogini. Ada empat hadis yang masuk kategori misoginis yang dicoba untuk dilihat, yaitu hadis tentang penciptaan perempuan, perempuan sebagai imam Shalat bagi laki-laki, laknat malaikat terhadap perempuan, dan kepemimpinan perempuan.

\footnotetext{
${ }^{10}$ Dalam konteks penelitian ini yang dimaksud dengan kyai adalah pengasuh pesantren.

${ }^{11}$ Tuti Harwati, Pemahaman Kyai terhadap Hadsts-hadist Misoginis (Yogyakarta: Tesis PPs UIN Sunan Kalijaga).
} 
Data utama tersebut didapatkan dari informan, yaitu pengasuh yang menjadi sasaran penelitian ini. Ada dua pengasuh yang menjadi sasaran penelitian, dua pengasuh ini berasal dari Pondok Pesantren Modern. Di sisi lain, penelitian ini juga akan didukung oleh data-data kepustakaan seputar hadis dan metodologi pemahamannya.

Data yang diperlukan dalam penelitian ini diperoleh dengan cara, wawancara mendalam (depth interview), dengan menggunakan pedoman wawancara yang telah dipersiapakan sebelumnya, pedoman wawancara itu berisi pertanyaan-pertanyaan seputar pemahaman pengasuh terhadap empat hadis misoginis di atas. Hasil dari wawancara itu kemudian dideskripsikan secara sistematis agar menghasilkan data yang dapat dibaca secara kritis. Pembacaan kritis terhadap pemahaman pengasuh pesantren dilakukan dengan alat bantu yang disebut dengan analisis isi.

\section{Hasil Penelitian}

\section{C.1 Pondok Pesantren al-Iman (Putri) Ponorogo}

\section{a. Penciptaan Perempuan}

Menurut Ustadz Iman pengasuh Pondok Pesantren al-Iman (Putri) sebenarnya tidak ada hadis yang menyatakan bahwa hawa itu dicipta dari tulang rusuk Adam, hadis itu muncul karena tambahan Asghar Ali Enginer terhadap teks hadis. Bahkan pengasuh Pondok Pesantren al-Iman ini menyatakan bahwa justru ada hadis yang menyatakan bahwa, "wanita itu saudara perempuan" (al-nisa' syaqấ'iq al-rijal), kata Syaqâ' berarti saudara, jadi perempuan itu adalah saudaranya laki-laki, bukannya hawa diambil dari tulang rusuknya, yang kemudian itu dijadikan dalil bahwasanya perempuan itu lebih rendah daripada laki-laki.

Selanjutnya pengasuh itu berpandangan bahwa pada dasarnya perempuan dan laki-laki itu sama saja, dalam hal apa saja, dalam hal pembebanan, hal hudud, jinayat, ta'lim, tarbiyah semuanya sama saja antara laki-laki dengan perempuan kecuali jika ada sesuatu yang tidak sesuai dengan kodratnya sebagai laki-laki dan perempuan. Laki-laki memiliki ketentuan-ketentuan hukum sendiri, misalnya dalam persoalan "waratsah dan al-qawwamah",. Perbedaan itu harus ada karena sudah tidak sesuai 
lagi dengan kodrat perempuan, karena itu yang menjadi "qawwamah" adalah lakilaki.

Tapi yang menarik dari pemahaman pengasuh pesantren ini, adalah beliau tidak setuju jika perempuan dikatakan diciptakan dari tulang rusuk Adam, dengan alasan adanya ayat al-Qur'an yang menyatakan bahwa manusia itu baik laki-laki maupun perempuan dicipta dari nafs yang sama atau satu ("min nafsin wahidah"). Berdasarkan ayat tersebut maka tidak alasan untuk menyatakan bahwasanya perempuan adalah makhluk nomor dua. Jika ada pandangan demikian, maka pandangan itu hemat mereka adalah "salah kaprah". Sebab menurut mereka pada dasarnya perempuan itu adalah saudara kandungnya laki-laki, yang disebut saudara, mestinya dihadapan orang tua adalah sama. Sebagaimana ada ayat yang dimulai dengan ungkapan: ya ayyuha al-nas maka yang dimaksud adalah laki-laki dan perempuan. Karena itu tidak ada perbedaan antara perempuan dan laki-laki.

Menurutnya lagi, gerakan feminisme hanya mengambil hadis-hadis yang kira-kira memojokkan saja tanpa melihat hadis yang lain, tidak membuat balance, tidak melihat secara menyeluruh, jadi memilih-milih saja, padahal kalau dibandingkan dengan hadis lain yang lebih kuat derajatnya atau kalau di-takhrij, bisa jadi hadis yang diambil oleh kaum feminis ini lebih lemah dari hadis-hadis lain yang lebih kuat derajatnya, jadi mereka mengambil hadis, kemudian dipilih atau diplot untuk tujuan memojokkan, dan itu sering terjadi. Kerena itu, hadis "al-nisa syaqa'iq al-rijal" menjawab gerakan feminisme yang memojokkan Islam.

Dalam tataran empirik, hadis al-nisa' syaqâiq al-rijal, terbukti kebenarannya, indikatornya adalah sukses pemimpin dunia selalu atas bantuan perempuan. Hanya saja secara kodrati perempuan dan laki-laki itu berbeda. Dan di Barat sendiri perbedaan kodrati itu dihormati, jika tidak, mestinya perbedaan toilet untuk perempuan dan laki-laki tidak perlu ada.

Persoalan-persoalan perempuan kontemporer saat ini, menurut pengasuh pesantren al-Iman, mestinya menjadi tantangan bagi Islam, karena itu yang perlu dilakukan adalah memahami ayat-ayat atau hadis-hadis seputar perempuan berdasarkan setting sosial perempuan kontemporer, namun demikian dalam upaya pemahaman itu, kita 
perlu mempertahan mana yang qath'i dan tsawabith. Reaktualisasi yang dikembangkan oleh Munawir Sadzali yang menyatakan bahwa hukum waris Islam itu tidak adil, tidak tepat untuk dipilih. Ketidakadilan hukum waris Islam menurut Munawir, karena menggunakan model pembagian waris 1:2, yaitu bagian 1 anak laki-laki sama dengan bagian dua anak perempuan. Sebelum mengatakan hukum waris itu tidak adil, mestinya harus dipahami dulu apa itu hukum waris Islam, sebenarnya model pembagian 1:2 dalam hukum waris Islam itu mempertimbangkan kodrat jasmani perempuan dan kodrat lakilaki sebagai suami. Mestinya hikmah dibalik pembagian waris Islam 1:2 itu perlu diperhatikan.

\section{b. Perempuan menjadi Imam Shalat}

Hadis yang sering dirujuk untuk melegitimasi perempuan untuk menjadi imam adalah hadis Ummu Waraqah. Hadis tersebut memang ada tapi jarang dikutip secara detail dalam kutub al-sittah. Hadis itu dapat ditemukan dalam kitab Mughni Muqaddamah dari madzhab Ahmad bin Hanbal, dalam kitab itu, ada satu fashl yang mengkaji hadis itu secara khusus, dalam hadis itu dikatakan bahwa ada yang meminta izin mengimami di rumah untuk anak-anaknya dan disebutkan ada laki-laki renta, jadi Ummu Waraqah mengimami anak-anak kecil dan laki-laki renta itu maka diizinkan oleh Rasul. Hanya hadits itu saja yang menjadi landasan untuk membolehkan perempuan untuk menjadi imam. Tetapi sebagian ulama' pun melihat bahwa kebolehan itu dengan syarat yaitu apabila dalam kondisi sangat terpaksa dan itu tidak boleh di tempat umum, sebab Ummu Waraqah memang menjadi imam di rumah, saat anak kecil itu belum bisa menjadi imam secara benar, laki-laki dalam hadits itu mungkin betul-betul renta, pikun, stroke atau bagaimana, dalam kasus ini tidak ada yang menafsirkan secara detail, dan saya juga belum mendapatkan. Yang jelas kebolehan untuk menjadi imam dalam kasus hadis Ummu Waraqah sifatnya terbatas dan tidak umum, kalau untuk umum apalagi menjadi khatib, imam, apalagi di situ ada di depan laki-laki tentu saja menurut beliau tidak boleh.

Logikanya begini, jika seorang imam lupa sesuatu apakah itu jumlah rakaat atau yang lainnya dalam shalat jama'ah, maka jika yang mengingatkan itu perempuan hendaknya ia bertepuk dan tidak boleh dengan tasbih, ini menunjukkan bahwasanya 
suara wanita itu harus sangat dijaga, kemudian bagaimana mungkin dia menjadi imam yang jama'ahnya terdiri dari laki-laki dan perempuan. Sedangkan suaranya saja harus dijaga. Hemat pengasuh hadis Ummu Waraqah itu adalah hadis yang secara khusus menunjuk kebolehan perempuan menjadi imam jika jama'ahnya itu anak-anak kecil dan laki-laki renta yang sudah tidak lagi punya syahwat.

\section{c. Dilaknat Malaikat}

Adapun pendapat Pengasuh Pesantren ini terhadap hadis yang menyatakan bahwa Malaikat melaknat seorang isteri yang menolak ajakan suami untuk bersetubuh? Adalah Hadis itu mestinya harus dipahami secara cermat, misalnya

dipertanyakan isteri yang bagaimana yang dilaknat. Hemat pengasuh tidak semua isteri kemudian dilaknakan hanya sekedar menolak permintaan suaminya. Jadi yang dilaknat itu adalah isteri yang menolak tanpa alasan. Misalnya dia tidak pernah siap untuk meladeni sang suami. Sedangkan itu menjadi salah satu kewajiban bagi sang isteri, menjadi hak bagi suami. Karena dalam asas Islam, akad nikah itu kan laki-laki membayar mahar, muqabilnya adalah bintu mar'ah. Artinya adalah agar isteri meladeni suami. Salah satu cara untuk mencapai keluarga sakinah adalah isteri melayani secara biologis. Jika ini telah terpenuhi, maka ketenangan batin dan lain sebagainya akan tercapai. Jadi, kalau hal itu tidak dimaksimalkan oleh isteri, maka itu akan mengancam perjalanan bahtera keluarga. Sehingga kata melaknat itu artinya mungkin seorang isteri yang tidak berusaha maksimal dalam meladeni suami. Jadi, laknat malaikat itu turun kepada isteri yang tidak melayani suami secara maksimal. Tapi ada baiknya dalam memahami hadits ini kita melihat setting masyarakat Arab ketika hadits itu disabdakan, sebab wanita Arab itu lebih susah diatur. Kalau Anda menikah dengan wanita Arab, satu yang harus direlakan, anda tidak akan dihormati. Dari panggilan saja, tidak ada kata mas atau pak. Tapi langsung memanggil nama. Jadi, mungkin menolak ajakan suami itu bagi perempuan Arab itu volumenya lebih sering, maka lahirlah hadits ini. Agar wanita-wanita Arab itu bisa menghormati suaminya.

\section{d. Kepemimpinan Politik Perempuan}


Memang hadis ini banyak dipegang para ulama untuk tidak memberi hak politik kepada para wanita, tapi akhirnya pemahaman terhadap hadis ini menjadi fleksibel. Walaupun belum pada tingkatan pada pemimpin segala hal. Di Negara Arab itu lebih mengerikan. Di negara Arab itu masih sulit menerima kalau wanita itu menjadi pemimpin. Ulama berbeda pendapat dalam memahami hadis ini, Imam Thabrani membolehkan. Di lain pihak, ada ulama yang sangat hati-hati dalam membolehkan perempuan untuk menjadi pemimpin.

\section{C.2 Pondok Pesantren Wali Songo Ngabar Ponorogo}

\section{a. Penciptaan Perempuan}

Bagi ustadz Heru Saiful Anwar Pengasuh Pondok Pesantren Wali Songo Ngabar Ponorogo, ungkapan jiwa yang satu itu ada dua penafsiran, yang pertama dari jiwanya adam, yang kedua dari jenis (sama-sama) manusia. Penafsiran dari jiwa yang satu ini, dari jiwa adam, di kuatkan dari hadis Rasul yang diriwayatkan oleh imam muslim, bahwa yang berbunyi wanita diciptakan dari tulang rusuk yang bengkok, maka janganlah engkau berusaha untuk meluruskannya, meluruskan sama dengan mematahkan, mematahkan sama dengan menceraikannya. Ini dari dhahir hadis dan ayat yang kita dapati sedemikian itu. Kalau dipahami bahwa perempuan diciptakan dari jiwa yang satu, dari jenis manusia, dari jenis yang sama, tidak dipungkiri tetap sama-sama manusia, dari jenis/jiwa yang sama, cuma onderdil dalamnya oleh Allah diberikan sendiri-sendiri, satu lebih kuat otaknya, intelektualnya, lebih rasional, dan yang satu emosinya lebih kuat. Maka hak dan kewajibannya sendiri-sendiri. Dua penafsiran itu bisa kita taufiq-kan, bisa kita kompromikan. Kalau menurut saya dari jenis manusia, karena sama-sama manusia, tapi kalau dari tulang rusuk yang bengkok, itu ada penelitian, bahwa ada yang membedakan antara tulang rusuk wanita dengan laki-laki. Dan memang ada, dalam tulang rusuk laki-laki seperti ada yang patah, perempuan tidak, komplit, sempurna. Ini dari semenjak adam, diambil tulang rusuknya untuk menciptakan hawa. Maka tulang rusuk laki-laki berbeda dengan perempuan.

\section{b. Perempuan Menjadi Imam Sholat}


Ketika ditanya pemahaman terhadap hadits tentang perempuan yang menjadi imam shalat bagi laki-laki, pengasuh pesantren ini hanya menjawab singkat, bagi saya selama tidak ada contoh dari Rasul, maka imam itu harus laki-laki.

\section{c. Dilaknat malaikat}

Pendapat pengasuh sangat setuju dengan hadis ini sebab terjadinya perselingkuhan, mau kawin lagi atau lainnya, itu karena perempuan kerapkali tidak memperhatikan suaminya, terutama dalam masalah hubungan seksual. Kenapa Rasul saw, ketika kawin dengan Khadijah, sama sekali tidak memiliki keinginan untuk kawin dengan orang lain? Karena Khadijah sangat baik, dari segi apapun dan dia juga tidak pernah menolak apapun permintaan rasul. Ini menjadi alasan mengapa kemudian rasul tidak memiliki keinginan untuk menikah dengan orang lain. Lakilaki kerapkali ingin menikah lagi karena pelayanan dan sikap-sikap isterinya yang tidak baik.

Kemudian secapek apapun si perempuan harus melayani suaminya. Hanya begini, seorang laki-laki harus tahu kondisi dan tahu diri. Laki-laki atau suami yang semacam itu menurut beliau kurang memahami wanita dan inilah kemudian yang menyebabkan isteri minta cerai, atau bahkan bisa sampai membenci laki-laki.

\section{d. Kepemimpinan Politik Perempuan}

Bagi Ustadz Heru Saiful Anwar, perempuan tidak tepat untuk jadi pemimpin, terutama pemimpin politik sebab hingga saat ini, beliau belum melihat negara sehebat apapun yang dipimpin wanita menjadi maju. Katakanlah Inggris dulu dipimpin oleh Margaret tidak sebaik yang dipimpin oleh Tony Blair atau yang lainnya. Kemudian di Pakistan sendiri dan Banglades dipimpin oleh wanita juga. Dua negara tersebut tidak menjadi maju malah menjadi kacau. Jadi di banyak tempat bahkan sekecil desa pun ketika dipimpin wanita tidak ada yang maju. Karena itu menurut beliau arena politik bukan tempat perempuan.

Karena itu tempatkanlah perempuan pada fitrahnya. Ada ungkapan dalam bahasa Arab yang menyatakan bahwa perempuan itu Al-ummu madrosatul hayyah. Ibu itu adalah sekolah kehidupan atau dalam ungkapan lain disebutkan bahwa perempuan itu al-ummu madrasat al-Qubra. Ibu itu adalah sekolah yang paling besar. 
Tugasnya adalah mendidik anak itu agar menjadi baik atau tidak. Dan memang keberhasilan sebuah negara terlihat ketika ketika ibu-ibu itu bisa mendidik anak-anak mereka dengan baik, bukan malah meninggalkan keluarga. Kalau ibu meninggalkan keluarga maka banyak anak-anak yang broken, pemabuk dan lain sebagainya. Itu hanya karena ibu meninggalkan tugas utamanya. Mereka pergi dari arisan kearisan saja. Karena itu pekerjaan yang paling dekat dengan perempuan dan sesuai dengan kodratnya hanya dua, pertama guru dan kedua kesehatan. Dua pekerjaan ini membutuhkan ketelatenan dan kehalusan jiwa. Dan perempuanlah yang paling cocok untuk kedua pekerjaan itu. Pekerjaan lain seperti kehakiman, polisi tentara itu bukan kodrat perempuan, meskipun pada zaman nabi ada, tapi mereka bergerak dibelakang balik layar, tidak langsung. Maka, jika perempuan itu keluar dari kodratnya yang terjadi adalah kehancuran. Penelitian-penelitian menunjukkan ketika para wanita pergi ke Korea, Taiwan dan Hongkong untuk bekerja maka anak-anak mereka menjadi tidak terurus. Jadi urusan pendidikan anak-anak di serahkan kepada perempuan, sebab laki-laki tidak bisa mendidik anak dengan baik. Kekuatan perempuan terletak pada kehalusan, emosi dan kasih sayangnya. Sementara laki-laki pada otaknya, dan perempuan lebih banyak emosi. Faktor emosi inilah yang mudah dalam pendidikan dan kesehatan.

\section{Analisis}

Bagian ini akan menganalisis dua fokus utama, pertama, aspek metodologi yang digunakan pengasuh pesantren dalam memahami hadis, dan yang kedua, terkait dengan pemahaman pengasuh pesantren terhadap hadis misoginis.

Kita mulai dari yang pertama, yaitu tentang metodologi pemahaman hadis. Secara umum dapat dikatakan bahwa pengasuh pesantren yang diteliti tampaknya tidak memperhatikan aspek metodologis pemahaman hadits secara ketat. Dengan kata lain, mereka tidak terlebih dahulu melakukan kritik historis terhadap hadits yang hendak dipahami, seperti memeriksa apakah sanad dan matn hadis yang dipahami itu berkualitas shahih atau tidak. Meskipun pada kasus tertentu, mereka sempat juga menyatakan hadis ini shahih, seperti yang dilakukan oleh pengasuh pesantren Wali Songo, tapi pernyataan itu tidak diikuti oleh sikap kritis terhadap teks yang dihadapi. 
Di sisi lain, mereka juga tampaknya tidak memilih pendekatan tertentu dalam memahami hadis. Mereka secara langsung merujuk pada pendapat-pendapat ulama, di samping mencoba untuk melakukan "ijtihad" untuk mehamami matn hadis yang ada.

Kedua, pemahaman hadis. Pengasuh pesantren al-Iman seperti terlihat di atas, menilai bahwa laki-laki dan perempuan itu sama, karena itu beban hukum yang mereka terima juga sama. Namun pada sisi yang lain, beliau juga membedakan aturan-aturan yang secara khusus berlaku bagi perempuan. Seperti pembagian warisan (al-waratsah) dan peran laki-laki sebagai pemimpin rumah tangga (alqawwamah). Bahkan pembedaan demikian beliau nilai sebagai sesuatu yang bersifat kodrati yang harus diterima karena begitulah ketetapan agama. Hal demikian, dapat dikatakan bahwa pengasuh pesantren tersebut sejatinya belum mampu membedakan mana pembedaan perempuan dan laki-laki berdasarkan "jenis kelamin" (sex) yang merupakan kodrat yang tidak bisa dirubah, mana perilaku sosial yang merupakan hasil dari proses pembetukan sosial (social constructed). Hemat peneliti pembagian warisan bukanlah diatur berdasarkan "jenis kelamin", sama halnya dengan konsep alqawwamah, yang mengatur pembagian peran antara laki-laki dan perempuan dalam keluarga. Baik konsep al-waratsah maupun konsep al-qawwamah, sejatinya lebih merupakan pembedaan berdasarkan gender yang merupakan konstruksi sosial masyarakat Arab ketika itu. Karena itu, konsep al-waratsah maupun al-qawwamah bisa saja dirubah, terutama jika konsep-konsep tersebut melahirkan ketidakadilan gender.

Selanjutnya pengasuh pesantren al-Iman menyatakan adalah hadis tentang perempuan diciptakan dari tulang rusuk tidak ada, dan menilai bahwa Asghar Ali Enginer sebagai feminis Muslim yang mempopulerkan hadis tersebut. Tentu saja penilaian ini keliru sebab hadis tersebut disebutkan secara eksplisit pada kitab-kitab hadis semisal Shahih al-Bukhari ${ }^{12}$ dan Shahih Muslim ${ }^{13}$. Karena itu dapat dikatakan bahwa pengasuh pesantren ini kurang begitu teliti tentang adanya hadis yang secara eksplisit menyebutkan perempuan dicipta dari tulang rusuk. Di sisi lain, dapat juga

\footnotetext{
${ }^{12}$ Al-Bukhari, Shahih Bukhari, Bab Ahadist al-Anbiya' dan Bab Nikah.

${ }^{13}$ Muslim, Shahih Muslim, Bab al-Radla'ah.
} 
dikatakan, bahwa pengasuh pesantren ini dengan begitu saja menilai Asghar Ali sebagai penyebar hadis yang tidak benar, ini dapat dikatakan bahwa ada kepentingan untuk menolak informasi-informasi yang dibawa oleh feminis Muslim, meskipun misalnya informasi itu benar.

Pengasuh pesantren ini juga menyatakan bahwa tentang perempuan sebagai imam shalat bagi laki-laki itu tidak terdapat dalam kutub al-sittah, tapi terdapat dalam al-Mughni, tentu saja pernyataan ini bertentangan dengan bukti-bukti empiris tentang penyebutan secara eksplisit hadis-hadis tersebut dalam beberapa kitab hadis yang masuk kategori kutub al-sittah. Misalnya hadis tersebut disebutkan dalam kitab Sunan Abu Dawud ${ }^{14}$ dan Musnad Ahmad bin Hanbal. ${ }^{15}$ Di sisi lain, ia membolehkan perempuan menjadi imam shalat bagi laki-laki asal untuk kondisi yang terbatas, yaitu makmum shalatnya anak kecil dan laki-laki tua renta. Dan tidak membolehkan perempuan untuk menjadi imam shalat bagi laki-laki untuk kondisi terbuka secara umum. Salah satu alasan yang dibangun adalah karena suara perempuan itu aurat dan dapat mendatangkan nafsu bagi makmum laki-laki. Hemat peneliti penilaian bahwa suara perempuan itu aurat dan dapat mendatangkan nafsu bagi laki-laki, cenderung berprasangka buruk terhadap perempuan. Perempuan dalam konteks demikian selalu dinilai sebagai asal muasal lahirnya dosa bagi laki-laki, penilaian demikian tentu saja merupakan penilaian yang buruk terhadap perempuan.

Pemahaman yang agak posisitif terhadap hadis misoginis yang dilakukan oleh pengasuh pesantren al-Iman terlihat pada hadis tentang isteri yang dilaknat malaikat karena menolak ajakan suaminya. Menurutnya tidak semua perempuan dilaknat, yang dilaknat adalah mereka yang menolak ajakan suaminya tanpa alasan. Pemahamannya terhadap hadits ini bisa dikatakan konstektual, terutama ketika ia mencoba untuk melihat setting masyarakat Arab ketika hadis itu muncul kemudian membandingkan dengan kondisi masyarakat Indonesia sekarang. Hadis ini lahir untuk isteri-isteri Arab yang susah diatur sebab kenyataannya perempuan Arab itu kerapkali menolak ajakan suaminya.

\footnotetext{
${ }^{14}$ Abu Dawud, Sunan Abi Dawud, bab shalat.

${ }^{15}$ Ahmad bin Hanbal, Musnad Ahmad bin Hanbal, Jilid VI, 405.
} 
Terakhir, pengasuh pesantren memahami terhadap larangan perempuan untuk menjadi pemimpin dengan cara merujuk pendapat ulama. Menurutnya ada dua pendapat ulama dalam hal ini, Imam al-Thabrani menurutnya merupakan ulama yang membolehkan perempuan untuk menjadi pemimpin, sementara ulama lain ada yang sangat hati-hati untuk membolehkan perempuan jadi pemimpin. Pengasuh pesantren al-Iman sendiri lebih memilih pendapat ulama yang membolehkan.

Kita beralih ke pemahaman pengasuh pesantren Wali Songo. Menurut pengasuh pesantren ini perempuan itu dicipta dari jiwa yang satu. Jiwa yang satu tersebut memiliki dua penafsiran, pertama, jiwa adam dan yang kedua, jenis manusia. Penafsiran yang pertama, yaitu perempuan dicipta dari jiwa Adam dikuatkan oleh hadits bahwa perempuan itu dicipta dari tulang rusuk yang bengkok. Penafsiran yang kedua yang menyatakan bahwa perempuan itu dicipta dari jiwa yang satu, yaitu jenis manusia. Penafsiran demikian menurut pengasuh pesantren ini juga tidak bisa ditolak kebenarannya. Karena penafsiran yang pertama dan kedua terlihat bertentangan, maka menurutnya dua penafsiran itu dapat dikompromikan. Tapi kompromi yang dilakukan tidak begitu jelas. Beliau kemudian memilih penafsiran yang kedua yang menyatakan bahwa perempuan itu dicipta dari jenis yang sama, yaitu manusia.

Selanjutnya pengasuh pesantren Wali Songo menolak secara tegas perempuan menjadi imam shalat bagi lagi-laki, alasannya karena tidak ada contoh langsung dari Nabi. Pengasuh pesantren ini juga sangat setuju jika perempuan yang menolak ajakan suaminya itu dilaknat malaikat, sebab perempuan kerapkali tidak memperhatikan suaminya. Cuma katanya suami harus tahu diri dan tidak boleh arogan. Pemahaman demikian dapat dikatakan cenderung untuk menghormati perempuan sebagai isteri. Kemudian yang terakhir tentang perempuan yang menjadi pemimpin. Pengasuh pesantren ini menolak secara tegas perempuan menjadi pemimpin politik, sebab sampai sekarang belum ada negara yang maju karena dipimpin oleh perempuan. Pemahaman demikian hemat peneliti berlebihan dan menganggap rendah kemampuan kepemimpinan perempuan dan cenderung menganggap perempuan tidak memiliki kemampuan kepemimpinan sama sekali. Dengan demikian meskipun pada kasus 
tertentu pengasuh pesantren ini menghormati perempuan namun pada sisi yang lain beliau cenderung meredahkan perempuan.

\section{E. Kesimpulan}

Berdasarkan paparan analisis di atas, dapat dikatakan bahwa pengasuh pesantren kurang memperhatikan aspek metodologis pemahaman hadis, terutama aspek kritik historis terhadap sanad dan matn hadis. Di sisi lain, pengasuh pesantren tidak memilih pendekatan khusus dalam memahami hadis, padahal pemilihan pendekatan merupakan langkah yang urgen untuk dilakukan sebab dengan memilih pendekatan tertentu pemahaman terhadap hadits bisa dilakukan secara adil dan tidak diskriminatif terhadap perempuan.

Lebih jauh dapat dikatakan bahwa pemahaman pengasuh pesantren terhadap hadis ada yang bercorak diskriminatif terhadap perempuan dan ada juga yang tidak. Karena itu untuk menghindari pemahaman yang tidak ramah terhadap perempuan yang bersumber pada hadis, para pengasuh pesantren hendaknya memilih pendekatan tertentu, dan tidak sekedar mengutip pendapat-pendapat ulama yang belum tentu benar. 


\section{BIBLIOGRAFI}

Al-Bukhari, Shahih Bukhari. Beirut: dar al-Fikr, t.t..

Ali, Nizar, Memahami Hadits: Metode dan Pendekatan. Yogyakarta: CeSad YPI alHikmah, 2001.

Dawud, Abu, Sunan Abi Dawud. Beirut: Dar al-Fikr, t.t.

Echol, John M. dan Hasan Shadily, Kamus Inggris-Indonesia. Jakarta: Gramedia, 1995.

Fahham, A. Muchaddam, Hermeneutika Hadits. Ponorogo: STAINPO Press, 2004.

Faqih, Mansour, Analisis Gender dan Transformasil Sosial. Yogyakarta: Pustaka Pelajar, 1993.

Hanbal, Ahmad bin, Musnad Ahmad bin Hanbal.Beirut: Dar al-Fikr, t.th.

Ham, Musa Hadi, Konsep Evolusi Sunnah. Semarang: Aneka Ilmu, 2002.

Harwati, Tuti, Pemahaman Kyai terhadap Hadits-hadits Misoginis. Yogyakarta: Tesis PPs UIN Sunan Kalijaga.

Isma'il, M. Syhudi, Metodologi Penelitian Hadis Nabi. Jakarta: Bulan Bintang, 1992.

Mernissi, Fatimah, Wanita dalam Islam. Bandung: Pustaka, 1991.

Muslim, Shahih Muslim. Surabaya: Syirkah Maktabah wa Matba'ah Musthafa alBabi al-Halabi, 1964.

Subhan, Zaitunah, Tafsir Kebencian: Studi Bias Gender dalam Tafsir al-Qur'an. Yogyakarta: LKiS, 1993.

Umar, Nasaruddin, Argumen Kesetaraan Gender dalam al-Qur'an (Jakarta: Paramadina, 1999. 